\title{
ION INPUT VIA RAINWATER IN THE SOUTHWESTERN REGION OF RIO GRANDE DO SUL, BRAZIL
}

\author{
Francine Neves Calil ${ }^{1}$, Mauro Valdir Schumacher ${ }^{2}$, Rudi Witschoreck ${ }^{3}$, \\ Vicente Guilherme Lopes ${ }^{3}$, Márcio Viera ${ }^{4}$, Edenilson Liberalesso ${ }^{5}$
}

(received: October 9, 2009; accepted: May 28, 2010)

\begin{abstract}
Ion input via rainfall alone and after interception by the forest canopy, constitutes an important path of biochemical cycling, although few studies have provided information on the subject so far. The objective of this work is to quantify ion inputs, via rainfall, in the southwestern region of Rio Grande do Sul state, Brazil. Ten rain gauges were mounted in a field area. The quantification of stored water volume, along with sample collection for determination of nitrate, nitrite, ammonium, phosphorus, sulfur, chlorine, calcium, magnesium, potassium and sodium contents, was done fortnightly from September 2006 to August 2008. Local annual average precipitation in the relevant period was 1,588.3 mm. The concentration of chemical elements in rainwater was found to vary throughout, being inversely correlated with the increase in rainfall, while potassium, ammonium, phosphate, sulfate, chloride and sodium were found to have a significant mutual correlation ( $\mathrm{p}<0.01$ ). Based on the annual amount of nutrient input via rainwater, it can be inferred that rainfall is an important source of chemical element input into the forest system.
\end{abstract}

Key words: Rainfall, chemical elements, atmospheric deposition.

\section{APORTE DE ÍONS VIA ÁGUA DA CHUVA NA REGIÃo SUDOESTE DO RIO GRANDE DO SUL, BRASIL}

RESUMO: O aporte de íons da precipitação pluviométrica isolada e também após passagem pelas copas das árvores, constitui uma importante via da ciclagem bioquímica; entretanto ainda são poucos os estudos que disponibilizam este tipo de resultado. Objetivouse, neste estudo, quantificar a entrada de íons, via precipitação pluviométrica, na região Nordeste do Rio Grande do Sul, Brasil. Em uma área de campo, instalou-se 10 pluviômetros. A quantificação do volume de água armazenado, bem como a coleta de amostras para determinação de nitrato, nitrito, amônio, fósforo, enxofre, cloro, cálcio, magnésio, potássio e sódio foram realizadas quinzenalmente de setembro de 2006 a agosto de 2008. A precipitação média anual ocorrida no período foi de 1.588,3 mm. A concentração dos elementos químicos na água da chuva apresentou-se variável durante o período de estudo, com correlação inversa ao aumento da pluviosidade, sendo que o potássio, amônio, fosfato, sulfato, cloreto e sódio apresentaram correlação significativa mútua ( $p<0,01)$. Com base na quantidade anual de aporte de nutrientes pela água da chuva, pode-se inferir que a pluviosidade é uma importante fonte de entrada de elementos químicos no sistema.

Palavras-chave: Pluviosidade, elementos químicos, deposição atmosférica.

\section{INTRODUCTION}

Water is an essential element for the existence of living beings, animal or vegetal, being an indispensable element for the economic development, health and general welfare of society. The key role played by water in the current geopolitical context has prompted research studies to try and preserve water quality, improve its use and application conditions, and analyze its chemical composition in a given system.
Rainfall, also known as wet precipitation, is a natural atmosphere cleansing process that draws existing chemical elements and compounds and deposits them on the earth's surface (SCHEER 2009). Atmospheric composition is influenced both by natural and anthropogenic sources, and results from the incorporation of particles and gases into water droplets (PANETTIERE et al. 2000).

According to Lara et al. (2001), Migliavacca et al. (2004) and Souza et al. (2007), the chemical composition of

\footnotetext{
${ }^{1}$ Forest Engineer, Dr. Professor of the Forest Engineering program of the Universidade Federal de Goiás /UFG - Rodovia Goiânia/Nova Veneza, Km 0 - Cx. P. 131 - 74690-900 - Goiânia, GO - francine.calil@ terra.com.br

${ }^{2}$ Forest Engineer, Dr. - Laboratório de Ecologia Florestal - Universidade Federal de Santa Maria - Prédio 44, Sala 5268 - $97105-900$ Santa Maria, RS - mvschumacher@gmail.com

${ }^{3}$ Forest Engineer, M.Sc. - Laboratório de Ecologia Florestal - Universidade Federal de Santa Maria - Prédio 44, Sala 5268 - $97105-900$ Santa Maria, RS - rwitschoreck@yahoo.com.br, viguilopes@yahoo.com.br

${ }^{4}$ Forest Engineer - Laboratório de Ecologia Florestal - Universidade Federal de Santa Maria - Prédio 44, Sala 5268 - $97105-900$ - Santa Maria, RS - vieraflorestal@yahoo.com.br

${ }^{5}$ Academic of the Forest Engineering program - Laboratório de Ecologia Florestal - Universidade Federal de Santa Maria - Prédio 44, Sala 5268 - 97105-900 - Santa Maria, RS - edeliberalesso@gamil.com
}

Cerne, Lavras, v. 16, n. 3, p. 373-380, jul./set. 2010 
rainwater is relatively controlled by contributions from sea (sea salt aerosols), continent (soil dust and biological emissions) and anthropogenic sources (industrial residue, biomass burning, vehicle emissions etc). An average hierarchic order of the distribution of major ions is as follows: $\mathrm{Cl}^{-}=\mathrm{Na}^{+}>\mathrm{Mg}^{2+}>\mathrm{K}^{+}>\mathrm{Ca}^{2+}>\mathrm{SO}_{4}^{2-}>\mathrm{NO}^{3-}>\mathrm{NH}^{4+}$ (STALLARD \& EDMOND 1981).

Variations in the composition of atmospheric precipitation are related to local input rates and seasonal variations in amount of rain, and the shorter the residence time of a gas or compound in the atmosphere, the greater the variation in its atmospheric concentration, in measures both over time and across geographic areas (MIGLIAVACCA et al. 2004). Nutrient inputs into any type of ecosystem may occur via precipitation and dust, and vary from place to place and according to season, being highly conditional on dust load and solar activity.

In studies conducted in various parts of Brazil, Moreira-Nordeman (2000) computed inputs, in $\mathrm{kg} \mathrm{ha}^{-1}$ year $^{-1}$, via the atmosphere, of the following amounts: in Fortaleza, 7.0 of $\mathrm{SO}_{4}^{2-}, 2.3$ of $\mathrm{NO}_{3}^{-}$and 1.4 of $\mathrm{NH}_{4}^{+}$; in Natal, 3.5 of $\mathrm{SO}_{4}^{2-}, 0.7$ of $\mathrm{NO}_{3}^{-}$and $0.5 \mathrm{of} \mathrm{NH}_{4}^{+}$; in Salvador, 15.8 of $\mathrm{SO}_{4}^{2-}, 1.6$ of $\mathrm{NO}_{3}^{-}$and 0.8 of $\mathrm{NH}_{4}^{+}$; in Niterói, 25.0 of $\mathrm{SO}_{4}^{2}, 6.3$ of $\mathrm{NO}_{3}^{-}$and 3.2 of $\mathrm{NH}_{4}^{+}$; in Caraguatatuba, 16.7 of $\mathrm{SO}_{4}^{2}, 8.0$ of $\mathrm{NO}_{3}^{-}$and 4.7 of $\mathrm{NH}_{4}^{+}$; and in Florianópolis, 12.8 of $\mathrm{SO}_{4}^{2-}, 6.0$ of $\mathrm{NO}_{3}^{-}$and $2.9 \mathrm{of} \mathrm{NH}_{4}^{+}$.

Existing nutrients in a forest ecosystem originate from two main natural sources: the weathering process and additions by rainfall. Maintenance of productivity over successive crop rotations depends on the speed with which new nutrients are released by weathering, addition through rainfall or artificial addition through fertilization (SCHRUMPF et al. 2006).

Given the key importance of studying the chemical composition of rainwater, and given the lack of scientific studies on cation and anion presence in local atmospheric precipitations, this study aims to quantify nutrient inputs into the southwestern region of Rio Grande do Sul state, Brazil.

\section{MATERIAL AND METHODS}

\subsection{Study site}

This study was conducted in an experimental area in Candiota-RS (Figure 1), a municipality located at geographic coordinates $31^{\circ} 45^{\prime} 50.7^{\prime \prime} \mathrm{S}$ and $53^{\circ} 50^{\prime} 34.9^{\prime \prime} \mathrm{W}$, at an altitude of $175 \mathrm{~m}$ above sea level.

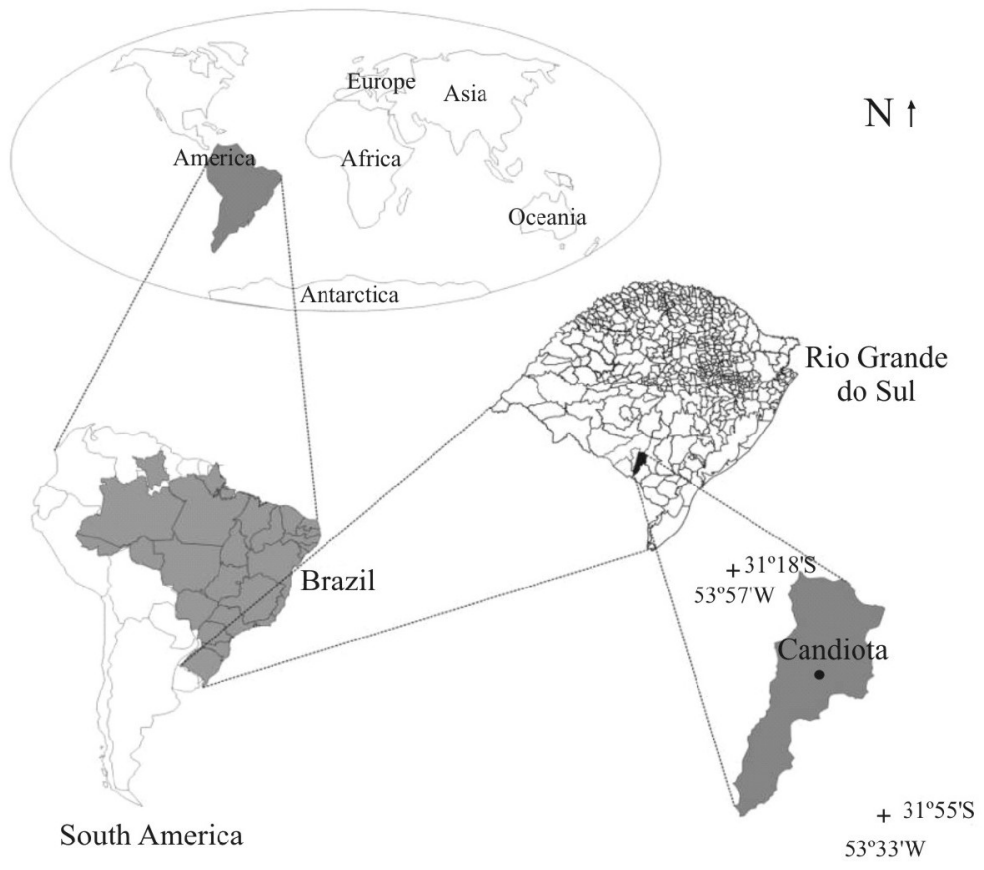

Figure 1 - Location map of Candiota, in the gaucho pampa.

Figura 1 - Croqui de localização do município de Candiota, no pampa gaúcho.

Cerne, Lavras, v. 16, n. 3, p. 373-380, jul./set. 2010 
The local climate, according to Köppen classification, is Cfa type, characterized as being subtropical, with average minimum temperatures of $17.8^{\circ} \mathrm{C}$ and average maximum temperatures of $28.9^{\circ} \mathrm{C}$. Average annual rainfall in the region is $1,414 \mathrm{~mm}$ (AGRITEMPO 2010).

The local soil is a $T a$ fragmentary litholic neosol with a clayey/gravelly clayey texture, and slightly rugged relief (STRECK et al. 2008).

Considering a straight-line horizontal distance, the study site is $162 \mathrm{~km}$ away from the sea, $168 \mathrm{~km}$ away from fertilizer plants and $28 \mathrm{~km}$ away from CGTEE Thermoelectric Power Plant.

\subsection{Rainwater collection}

In a field area within the study site 3.6 ha in area, 10 plastic funnels $23 \mathrm{~cm}$ in diameter were mounted for collecting rainwater (rain gauges), being positioned $1.50 \mathrm{~m}$ high (Figure 2).

From September 2006 to August 2008, rainwater was collected fortnightly and its volume was quantified using a graduated cylinder $(1 \mathrm{~L})$. Once rainfall was quantified, the water was then sampled (combined samples from two adjacent collectors) and stored in previously decontaminated plastic containers with a capacity of 500 $\mathrm{mL}$. At the end of each collecting procedure, rain gauges were rinsed and decontaminated using distilled water.

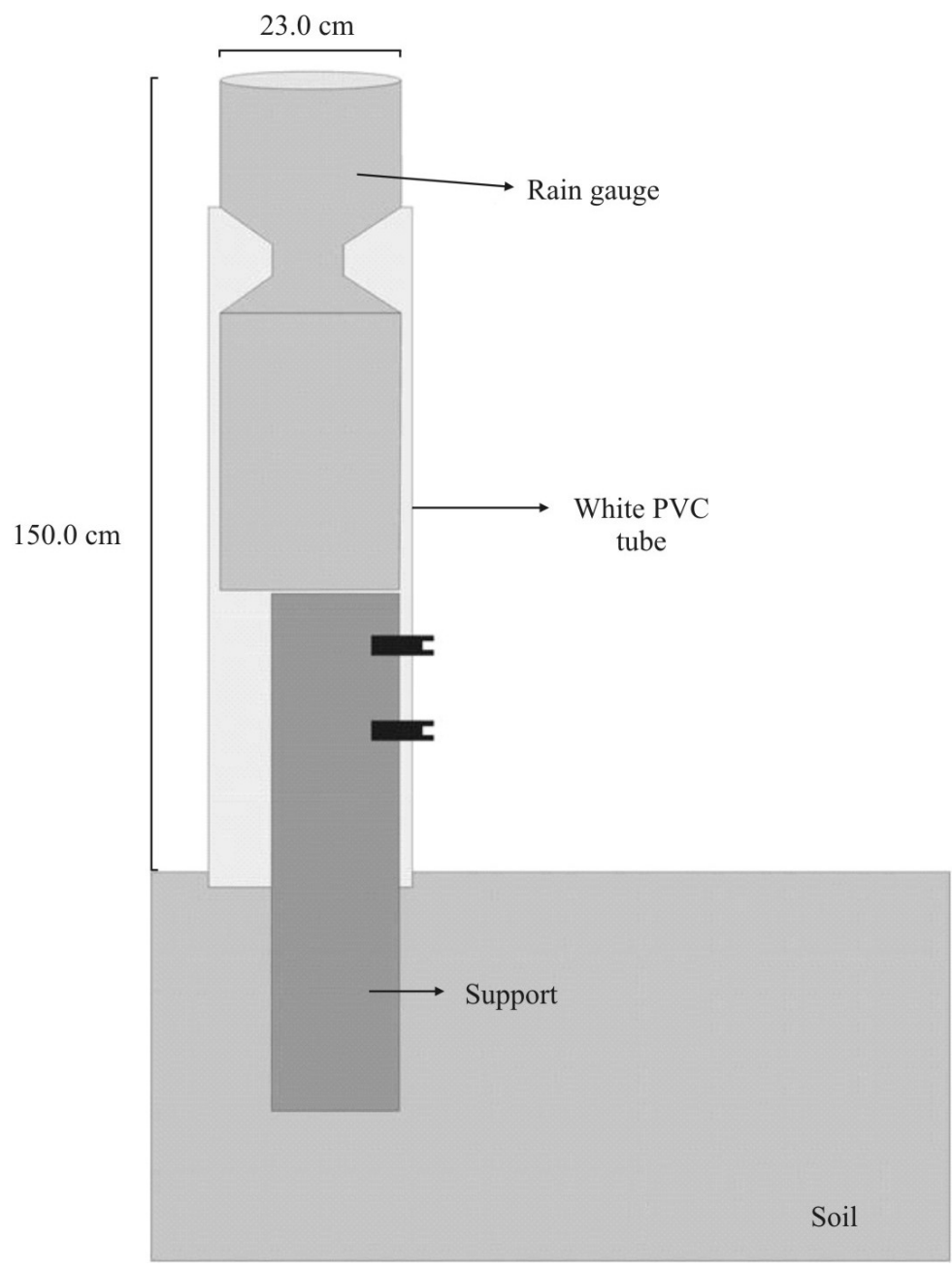

Figure 2 - Illustration of a collecting funnel (rain gauge) mounted in the experimental area, municipality of Candiota-RS.

Figura 2 - Esquema ilustrativo de um funil coletor (pluviômetro) instalado na área experimental, no município de Candiota-RS.

Cerne, Lavras, v. 16, n. 3, p. 373-380, jul./set. 2010 
The field-collected rainwater samples were submitted to the Laboratory of Forest Ecology of the Federal University of Santa Maria for content determination of nitrate, nitrite, ammonium, phosphate, sulfate, chloride, calcium, magnesium, potassium and sodium, according to the methodology 'Standard methods for examination of water and wastewater" - (AMERICAN PUBLIC HEALTH ASSOCIATION-APHA 1998), where they were subjected to simple filtering as a pretreatment $(0.45 \mu \mathrm{m}$ pores). Anions were then analyzed by ion chromatography: calcium and magnesium by atomic absorption spectrometry, potassium and sodium by flame photometry.

Based on results of chemical analyses and the volume of precipitation in the relevant period, nutrient input was calculated in a forested area with eucalyptus in the gaucho pampa. Statistical analyses were performed at the $5 \%$ error probability level, for the Pearson correlation analysis (r).

\section{RESULS AND DISCUSSION}

\subsection{Nutrient contents in rainwater}

Figures 3 (Time interval 1) and 4 (Time interval 2) illustrate monthly variation in rainfall, as well as monthly concentrations of cations and anions in the study site. The annual average rainfall throughout the study period was $1,588.3 \mathrm{~mm}$. This value is $12.3 \%$ higher than the historical average found in literature for the region.
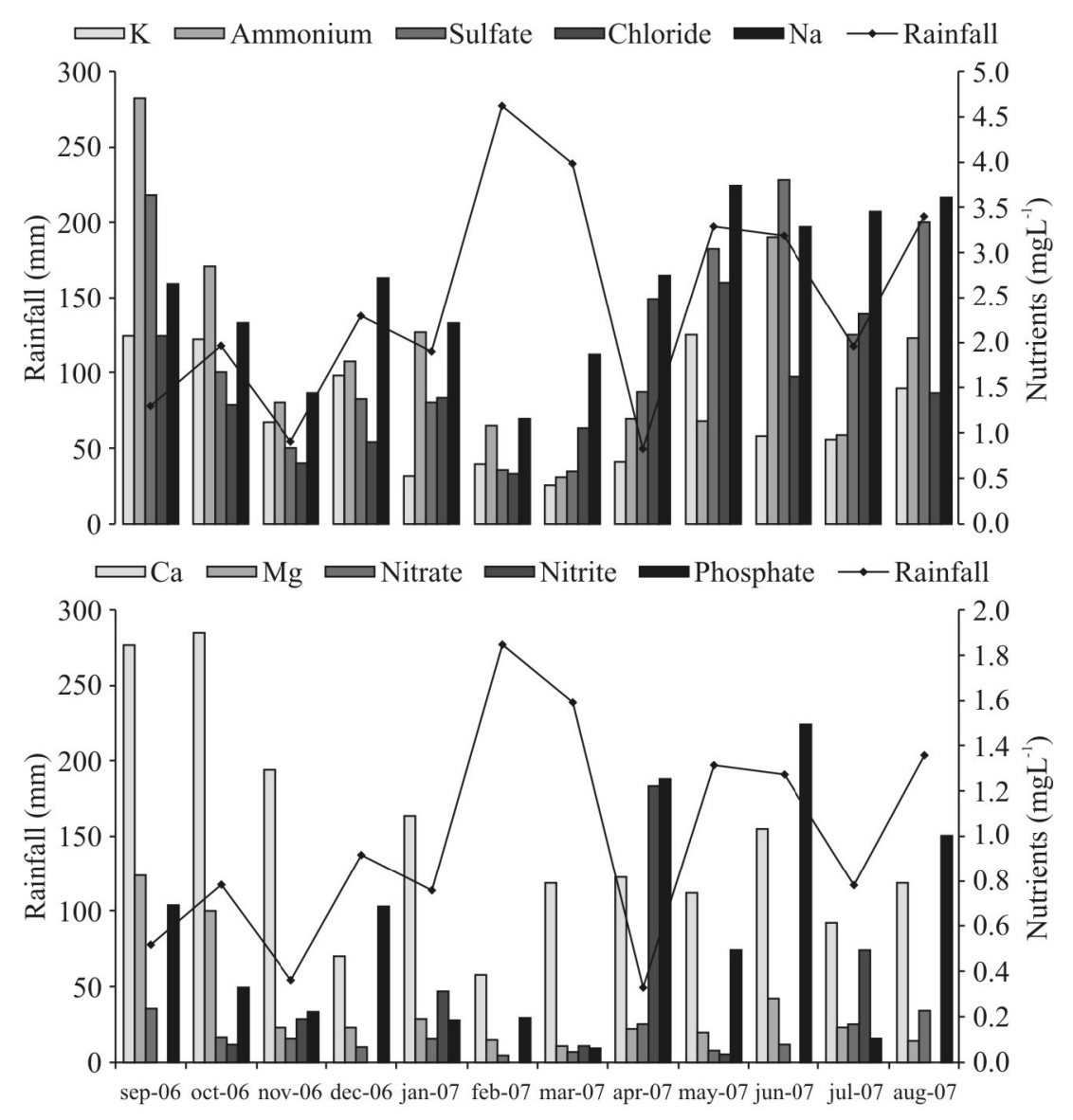

Time interval (month)

Figure 3 - Precipitation (mm) and ion concentrations (mg.L $\mathrm{L}^{-1}$ ) observed in the study site, from September 2006 to August 2007 , Candiota - RS.

Figura 3 - Precipitação $(\mathrm{mm})$ e concentrações de íons $\left(\mathrm{mg} . \mathrm{L}^{-1}\right)$ observados na área de estudo, no período de setembro de 2006 a agosto de 2007, Candiota $-R S$.

Cerne, Lavras, v. 16, n. 3, p. 373-380, jul./set. 2010 

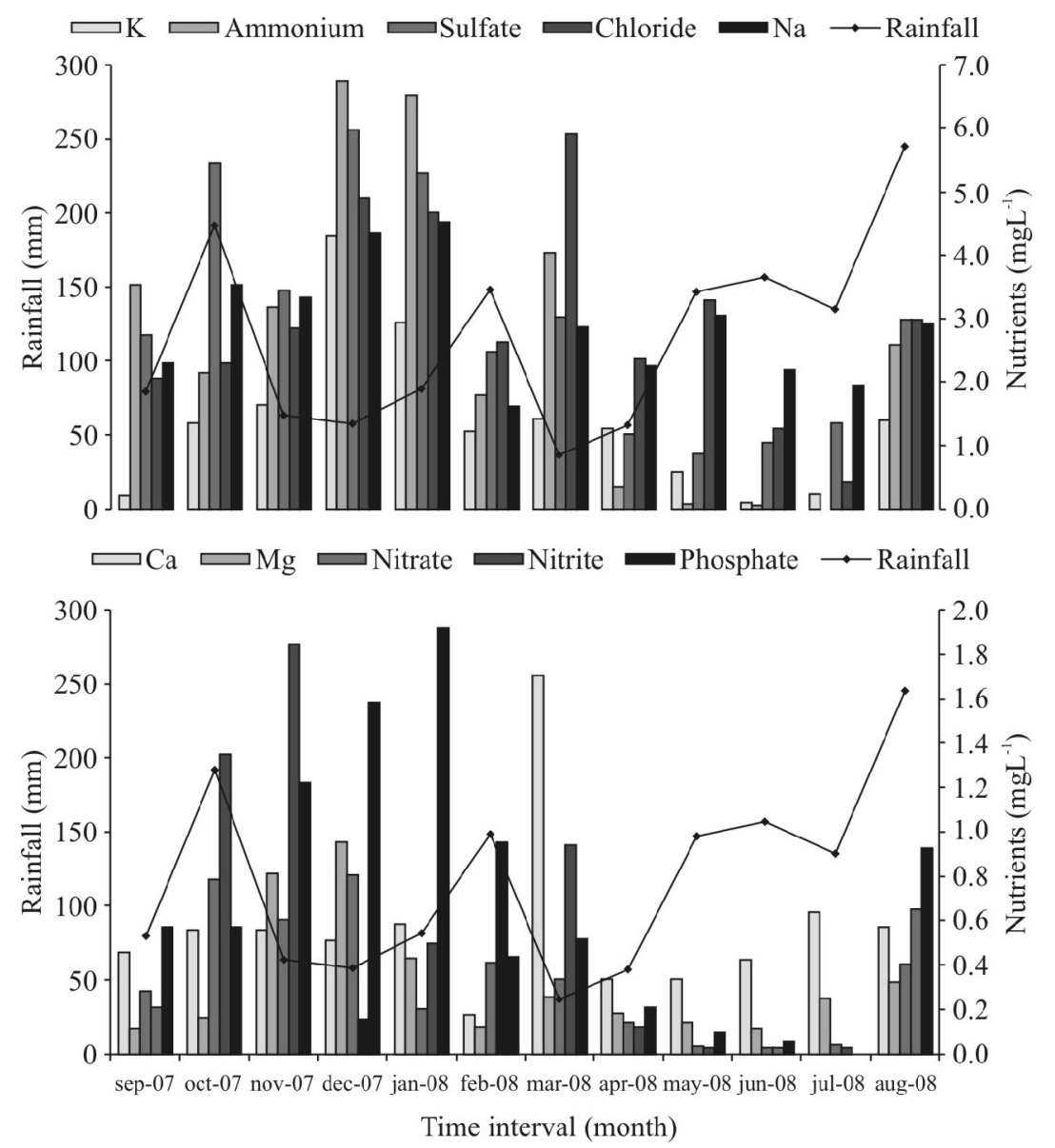

Figure 4 - Precipitation (mm) and ion concentrations (mg.L $\left.\mathrm{L}^{-1}\right)$ observed in the study site, from September 2007 to August 2008 , Candiota - RS.

Figura 4 - Precipitação $(\mathrm{mm})$ e concentrações de íons ( $\left.\mathrm{mg} . \mathrm{L}^{-1}\right)$, observados na área de estudo, no período de setembro de 2007 a agosto de 2008, Candiota-RS.

It should be noted that, in months where rainfall was more intensified, concentrations of elements tend to dissipate more, while, conversely, concentrations of elements tend to increase where rainfall volume decreases. This tendency can be observed in Table 1, especially concerning $\mathrm{Mg}$ and chloride contents, inversely and significantly correlated $(\mathrm{p}<0.05)$.

In a study of major ion composition of rainfall in São Paulo city center, Leal et al. (2004) found a $\mathrm{Na} / \mathrm{Cl}$ ratio of 1.75 , which is outside the $0.5-1.5$ range recommended by the European Union's air pollution study group for indicating a marine source, therefore they decided not to regard marine breeze as sole source of sodium. Despite the high correlation between sodium and chloride $(r=0.94)$, the authors considered that not only chloride but also magnesium, calcium and sulfate ions originate predominantly from continental/anthropogenic sources.

The high concentrations of sodium $(\mathrm{Na})$ could be related to the close proximity of the study to the sea. Walling (1980), as cited by Arcova et al. (1985), considers that, when the main source of aerosols is the sea surface, the atmosphere will be rich in $\mathrm{Na}, \mathrm{Cl}, \mathrm{Mg}$ and $\mathrm{K}$. It is also believed that concentrations of chemical elements could be influenced by wind and air masses originating from the coastal region, the thermoelectric plant and manure/fertilizer plants.

The correlation matrix, as applied to concentrations of elements in rainwater and to total rainfall, considered significant indices of correlation with probability $\mathrm{p}<0.01$ or $\mathrm{p}<0.05$. 
Table 1 - Pearson correlation analysis (R) for relevant variables concerning precipitation in a eucalyptus stand.

Tabela 1 - Análise de correlação de PEARSON $(R)$, para as variáveis estudadas na precipitação incidente num povoamento de eucalipto.

\begin{tabular}{|c|c|c|c|c|c|c|c|c|c|c|c|}
\hline & Rainfall & K & $\mathrm{Ca}$ & $\mathrm{Mg}$ & Nitrate & Nitrite & Ammonium & Phosphate & Sulfate & Chloride & $\mathrm{Na}$ \\
\hline Rainfall & 1 & & & & & & & & & & \\
\hline K & -0.28 & 1 & & & & & & & & & \\
\hline $\mathrm{Ca}$ & -0.23 & 0.19 & 1 & & & & & & & & \\
\hline $\mathrm{Mg}$ & $-0.41 *$ & $0.71 * *$ & $0.48 *$ & 1 & & & & & & & \\
\hline Nitrate & -0.33 & $0.43^{*}$ & 0.03 & 0.37 & 1 & & & & & & \\
\hline Nitrite & -0.28 & 0.06 & -0.15 & 0.26 & $0.56^{* *}$ & 1 & & & & & \\
\hline Ammonium & -0.38 & $0.77 * *$ & 0.32 & $0.70 * *$ & $0.54 * *$ & 0.15 & 1 & & & & \\
\hline Phosphate & -0.28 & $0.79 * *$ & -0.04 & $0.58 * *$ & 0.37 & 0.15 & $0.82 * *$ & 1 & & & \\
\hline Sulfate & -0.15 & $0.72 * *$ & 0.13 & $0.53 * *$ & $0.62 * *$ & 0.29 & $0.80 * *$ & $0.77 * *$ & 1 & & \\
\hline Chloride & $-0.43 *$ & $0.57 * *$ & -0.01 & 0.36 & $0.72 * *$ & 0.34 & $0.62 * *$ & $0.58 * *$ & $0.61 * *$ & 1 & \\
\hline $\mathrm{Na}$ & -0.16 & $0.65 * *$ & -0.04 & 0.38 & 0.37 & 0.2 & $0.57 * *$ & $0.71 * *$ & $0.79 * *$ & $0.63 * *$ & 1 \\
\hline
\end{tabular}

* Significant correlation $(\mathrm{p}<0.05)$; ** Significant correlation $(\mathrm{p}<0.01)$.

The group represented by potassium, ammonium, phosphate, sulfate, chloride and sodium corresponds to cations and anions showing a significant mutual correlation, with overall indices above 0.57 . These homogeneous correlations between the above elements probably indicate similar sources or similar behavior patterns in the study site.

In a study conducted in Uruguay by Zunckel et al. (2003), the authors observed the existence of significant correlations between concentrations of chemical elements in rainwater. A correlation was observed between chlorine, sodium and magnesium due to the marine source contribution to chemical characteristics of rainwater. The correlation between nitrate and ammonium, in turn, is mainly attributed to cattle raising and fertilizer use, while the correlation between calcium and magnesium is attributed to other sources such as unpaved roads, wind-carried dust from bare grounds, and soil tillage.

For Quiterio et al. (2005), however, high levels of $\mathrm{Na}$ and $\mathrm{K}$ are also ascribable to biomass burning, other than to close proximity to the sea. According to Miglavacca et al. (2005), concentrations of chemical elements in rainwater are influenced by anthropogenic factors, including: thermoelectric plants, ironworks, fertilizer plants and residue burning, in addition to natural factors (CAMPOS et al. 1998) such as sea salt spray.

Cerne, Lavras, v. 16, n. 3, p. 373-380, jul./set. 2010

\subsection{Amount of ions in rainfall}

Figure 5 illustrates the amount of ions $\left(\mathrm{kg} \mathrm{ha}^{-1}\right)$ contained in rainwater. As far as total ion amount via rainfall is concerned, it was noted in this study that sodium was the element contributing the highest input into the system over the two-year study period, a total of $80.7 \mathrm{~kg} \mathrm{ha}^{-1}$, followed by nitrogen $(68.00)$, chlorine (55.00), potassium (34.70), calcium (22.80), sulfur (21.10), and phosphorus (17.80), while magnesium was the element contributing the lowest input, a total of $7.20 \mathrm{~kg}$ ha $^{-1}$.

In a study intended to investigate chemical characteristics of rainwater in Campos de Cima da SerraRS region, Schumacher et al. (2008a) observed the following total inputs into the system: 39.67 of Na; 8.81 of $\mathrm{K} ; 5.95$ of $\mathrm{Ca} ; 1.20$ of $\mathrm{Mg} ; 8.99$ of $\mathrm{N} ; 2.64$ of $\mathrm{S}$ and 1.36 of $\mathrm{P}$, in $\mathrm{kg}$ $\mathrm{ha}^{-1}$ year $^{-1}$. For the central region of Rio Grande do Sul, Schumacher et al. (2008b) observed the following total inputs: 6.92 of $\mathrm{K} ; 2.78$ of $\mathrm{Ca}$ and 0.60 of $\mathrm{Mg}$, in kg ha ${ }^{-1}$ year $^{-1}$. These values are significantly lower than findings in this study, which can be partially explained by more intensified rainfall in the region.

Ferreira et al. (2006) argue that, in studies concerning ion flow data in Floresta Adolpho Ducke reserve, near Manaus, they obtained the following values: 13.6 of chloride; 8.4 of sodium; 6.6 of ammonium, 2.4 of potassium and 0.1 of phosphate, in $\mathrm{kg} \mathrm{ha}^{-1} \mathrm{year}^{-1}$. 


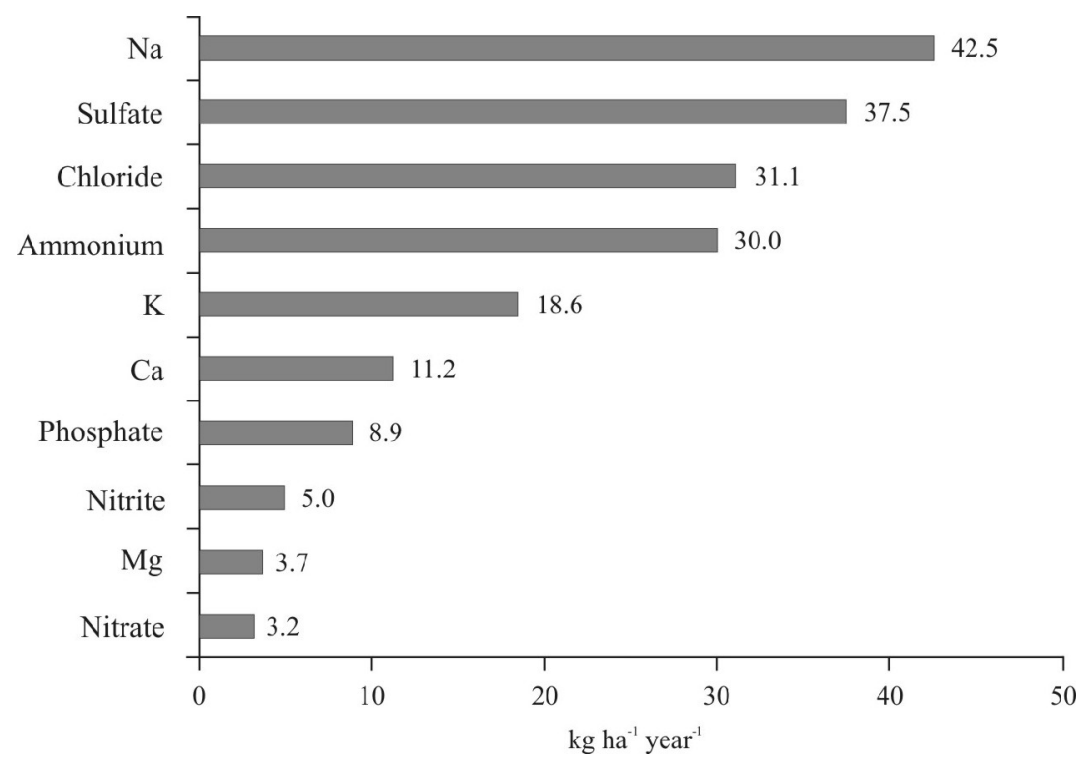

Figure 5 - Average annual ion input via rainfall $\left(\mathrm{kg} \mathrm{ha}^{-1}\right)$ in the study site, from September 2006 to August 2008, Candiota-RS.

Figura 5 - Entrada média anual de íons, via precipitação pluviométrica ( $\left.\mathrm{kg} \mathrm{ha}^{-1}\right)$, na área estudada, no período de setembro de 2006 a agosto de 2008, Candiota-RS.

Santos et al. (2006) obtained 0.6, 0.02 and $1.4 \mathrm{~g} \mathrm{~m}^{-2}$ year-1 as annual depositions of $\mathrm{NH}_{4}, \mathrm{NO}_{2}$ and $\mathrm{NO}_{3}$ respectively. Higher concentrations of $\mathrm{NO}_{2}^{-}$were observed in rainwater with $\mathrm{pH}>6.0$. In drier months, ammonium concentrations were found to be well above average, while for nitrate this role was not observed.

\section{CONCLUSIONS}

The concentration of chemical elements in rainwater was found to vary over the study period, showing an inverse correlation with increase in rainfall.

Ions potassium, ammonium, phosphate, sulfate, chloride and sodium showed a significant mutual correlation ( $\mathrm{p}<0.01)$.

Rainwater (precipitation) is an important source of chemical element inputs into the forest system.

\section{ACKNOWLEDGMENTS}

We wish to thank Votorantim Celulose e Papel, Rio Grande do Sul unit, for providing the experimental location and for their logistical and financial support.

\section{BIBLIOGRAPHICAL REFERENCES}

AGRITEMPO. Sistema de monitoramento agrometeorológico. Disponível em: sumario? $\mathrm{uf}=\overline{\mathrm{R}} \mathbf{\Phi}>$. Acesso em: 27 abr. 2010.
AMERICAN PUBLIC HEALTH ASSOCIATION. Standard methods for the examination of water and wastewater. 19. ed. Washington, 1998.

ARCOVA, F. C. S.; CICCO, V.; LIMA, W. P. Balanço dos nutrientes $\mathrm{Ca}^{++}, \mathrm{Mg}^{++}, \mathrm{Na}^{+}, \mathrm{K}^{+}$e $\mathrm{NO}_{3}^{-}$em bacia hidrográfica experimental com vegetação natural no Parque Estadual da Serra do Mar, núcleo Cunha, SP. Revista IPEF, Piracicaba, v. 31, p. 61-67, 1985.

CAMPOS, V. P.; COSTA, A. C. A.; TAVARES, T. M. Comparação de dois tipos de amostragem de chuva: deposição total e deposição apenas úmida em área costeira tropical. Química Nova, São Paulo, v. 21, p. 418-423, 1998.

FERREIRA, S. J. F.; LUIZÃO, F. J.; MIRANDA, S. A. F.; SILVA, M. S. R.; VITAL, A. R. T. Nutrientes na solução do solo em floresta de terra firme na Amazônia Central submetida à extração seletiva de madeira. Acta Amazonica, Manaus, v. 36, p. 59-68, 2006.

LARA, L. B. L. S.; ARTAXO, P.; MARTINELli, L. A.; VICTORIA, R. L.; CAMARGO, P. B.; KRUSCHE, A.; AYERS, G. P.; FERRAZ, E. S. B.; BALLESTER, M. V. Chemical composition of rainwater and anthropogenic inûuences in the Piracicaba River Basin, Southeast Brazil. Atmospheric Environment, v. 35, p. 4937-4945, 2001.

Cerne, Lavras, v. 16, n. 3, p. 373-380, jul./set. 2010 
LEAL, T. F. M.; FONTENELE, A. P. G.; PEDROTTI, J. J. Composição iônica majoritária de águas de chuva no centro da cidade de São Paulo. Química Nova, São Paulo, v. 27, p. 855861, 2004.

MIGLIAVACCA, D.; TEIXEIRA, E. C.; PIRES M.; FACHEL, J. Study of chemical elements in atmospheric precipitation in South Brazil. Atmospheric Environment, v. 38, p. 1641-1656, 2004.

MOREIRA-NORDEMAN, L. M. Impactos ambientais na precipitação da costa brasileira. [S.1.: s.n.], 2000.

PANETTIERE, P.; CORTECCI, G.; DINELLI, E.; BENCINI, A.; GUIDI, M. Chemistry and sulfur isotopic composition of precipitation at Bologna, Italy. Applied Geochemistry, v. 15, p. 1455-1467, 2000.

QUITERIO, S. L.; SOUSA, C. R.; ARBILLA, G.; ESCALEIRA, V. Evaluation of levels, sources and distribution of airborne trace metals in seven districts of the Baixada Fluminense, Rio de Janeiro, Brazil. Atmospheric Environment, v. 39, p. 3503-3512, 2005.

SANTOS, M. A.; ILLANES, C. F.; DAMASCENO, T. V. F.; FONTENELE, A. P. G.; PEDROTTI, J. J.; FORNARO, A. Determinação de compostos de nitrogênio em águas de chuva: $\mathrm{NH}_{4}, \mathrm{NO}_{2}^{-}$e $\mathrm{NO}_{3}^{-}$. In: REUNIÃO ANUAL DA SOCIEDADE BRASILEIRA DE QUÍMICA, 29., 2006, Águas de Lindóia. Anais... Águas de Lindóia: SBQ, 2006.

SCHEER, M. B. Fluxo de nutrientes pela precipitação pluviométrica em dois trechos de Floresta Ombrófila Densa em Guaraqueçaba, Paraná. Floresta, Curitiba, v. 39, p. 117-130, 2009.
SCHRUMPF, M.; ZACH, W.; AXMACHER, J. C.; LYARUU, H. V. M. Biogeochemistry of an afrotropical montane rain forest on Mt. Kilimanjaro, Tanzania. Journal of Tropical Ecology, v. 22, p. 77-89, 2006.

SCHUMACHER, M. V.; TRÜBY, P.; LOPES, V. G. Características químicas da água em florestas de Pinus no sul do Brasil. Santa Maria: FATECIENS/DCFL/UFSM, 2008a. 57 p. Relatório parcial de pesquisa.

SCHUMACHER, M. V.; TRUBY, P.; NAVROSKI, M. C. Adição de nutrientes pela água da chuva em uma Floresta Estaciona: decidual em comparação com campo nativo em Itaara-RS, Brasil. Santa Maria: FATECINS/DCFL/UFSM, 2008b. 57 p. Relatório parcial de pesquisa.

SOUZA, V. V.; DIAS, H. C. T.; COSTA, A. A.; OLIVEIRA, J. C. Análise da qualidade das águas das precipitações em aberto e efetiva em um fragmento secundário da Mata Atlânctica, no município de Viçosa, MG. Revista Árvore, Viçosa, v. 31, p. 737743, 2007.

STALLARD, R. F.; EDMOND, J. M. Chemistry of the Amazon, precipitation chemistry and marine contribution to the dissolved load at the time of peak discharge. Journal Of Geophysical Research, v. 86, p. 9844-9858, 1981.

STRECK, E. V.; KÄMPF, N.; DALMOLIN, R. S. D.; KLAMT, E.; NASCIMENTO, P. C.; SCHNEIDER, P.; GIASSON, E.; SPINELLI PINTO, L. F. Solos do Rio Grande do Sul. 2. ed. Porto Alegre: Emater/RS, 2008. 222 p.

ZUNCKEL, M.; SAIZAR, C.; ZARAUZ, J. Rainwater composition in northeast Uruguay. Atmospheric Environment, v. 37 , p. 1601-1611, 2003. 